\title{
Cellulase Enzyme Production Using Solid State Fermentation Method From Waste - A Review
}

\author{
Siti Maftukhah \\ Jurusan Teknik Kimia, Fakultas Teknik, Universitas Islam Syekh Yusuf, Jl. Mulana Yusuf No.10 Tangerang Banten \\ 15118, Indonesia \\ $\underline{\text { sitimaftukhah@unis.ac.id }}$
}

\begin{abstract}
Solid fermentation (SSF) has built credibility in recent years in the biotechnology industry because its application has the potential to produce biologically active secondary metabolites, in addition to animal feed, fuel, food, industrial chemicals and pharmaceutical products, it has also emerged as an alternative interesting method that replaces the submerged fermentation method(SmF). This paper reviews the meaning of SSF, the factors that influence the success of SSF, the advantages and disadvantages of SSF, the meaning of cellulase enzymes, the use of cellulase enzymes and the production of cellulase enzymes using SSF from waste. The waste consists of agricultural waste and food processing waste with various microorganisms, optimization and pretreatment. So that the various levels of enzyme activity produced depend on the type of waste.
\end{abstract}

Keywords: cellulace enzyme, solid state fermentation (ssf), waste

\begin{abstract}
Abstrak. Fermentasi padat (SSF) telah membangun kredibilitas dalam beberapa tahun terakhir di industri bioteknologi karena aplikasinya sangat berpotensi dalam produksi metabolit sekunder yang aktif secara biologis, selain untuk pakan ternak, bahan bakar, makanan, bahan kimia industri dan produk farmasi, juga telah muncul sebagai alternatif metode yang menarik yang menggantikan metode fermentasi terendam (SmF). Makalah ini mengulas tentang pengertian SSF, faktor-faktor yang mempengarui keberhasilan SSF, kelebihan dan kekurangan SSF, pengertian enzim selulase, penggunaan enzime selulase dan produksi enzyme selulase menggunakan SSF dari limbah. Limbah tersebut terdiri dari limbah pertanian dan limbah pengolahan makanan dengan berbagai mikroorganisme, optimasi dan pretreatment. Sehingga berbagai tingkat aktivitas enzim yang dihasilkan tergantung pada jenis limbah.
\end{abstract}

Kata kunci: enzim selulase fermentasi padat, limbah

\section{Introduction}

Solid-state fermentation (SSF) is defined as the fermentation involving solids in absence (or near absence) of free water; however, substrate must possess enough moisture to support growth and metabolism of micro-organism. SSF stimulates the growth of micro-organisms in nature on moist solids and has been credited to be responsible for the beginning of fermentation technique in ancient time (Panday, 2003).

There are various important factors that produce immense impact on success of a particular technology hence, needed to be considered for the development of any bioprocesses and so is the SSF. It includes selection of microorganism and substrate, opti-mum process parameters and also purification of the end product, which has been a challenge for this technology. Fungi and yeast were termed as suitable microorganisms for SSF according to the theoretical concept of water activity, where as bacteria have been considered unsuitable. The establishment of the relationships between the physiol-ogy of the microorganisms and the physico-chemical factors is the aim for the development of proper models. These factors include temperature, $\mathrm{pH}$, aeration, water activity and moisture, bed proper-ties, nature of solid substrate employed, etc. Among several critical factors moisture and nature of solid substrate employed are the most important factor affecting SSF processes. Selection of mois-ture depends on microorganism employed and also the nature of substrate. Fungi needs lower moisture, 40-60\% moisture could be sufficient but selection of substrate depends upon several factors mainly related with cost and availability and thus may involve the screening of several agro-industrial residues (Singhania et al., 2009).

Continuous processes are emerging in SSF like $\mathrm{SmF}$, making it economically viable. There have been reports on development of continuous SSF process for the production of fungal tannase. A laboratory scale prototype reactor, with the specific aim in operating continuously with solid substrates and without inoculation of the feed was built and monitored 
successfully. Various bioreactor designs and their use for protein production under solid state fermentation (SSF) conditions using various agricultural byproducts have been discussed along with their advantages and disadvantages. Various products by different microorganisms employing different agroindustrial residues, using different reactors have been enlisted in Table 1. (Singhania et al., 2009).

SSF offers numerous advantages over SmF such as simpler technique and lower cost (Table 2). However, there are few designs available for bioreactors operating in solid-state conditions. This is principally due to several problems encountered in the control of different parameters such as $\mathrm{pH}$, temperature, aeration and oxygen transfer and moisture. SSF lacks the sophisticated control mechanisms that are usually associated with SmF. Control of the environment within the bioreactors is also difficult to achieve, particularly temperature and moisture (Couto and Samroman, 2006).

All the fermentation processes used in ancient times were based on the principles of solid-state fermentation technology; history indicates that it was lost in oblivion in western countries after 1940 due to emergence of submerged fermenta-tion technology

\begin{tabular}{|c|c|c|c|}
\hline Maroonganism/biocatalyst & Substrate & \multirow{2}{*}{$\begin{array}{l}\text { Rroduct } \\
\text { Sporers } \\
\text { citric said } \\
\text { Neutral metalloproctesse }\end{array}$} & \multirow{3}{*}{ 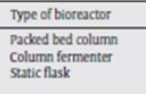 } \\
\hline 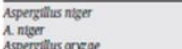 & \multirow{11}{*}{ 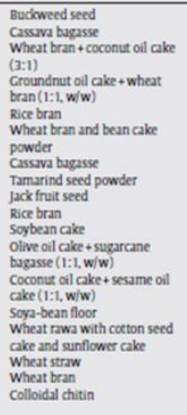 } & & \\
\hline 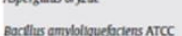 & & 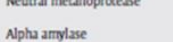 & \\
\hline 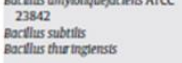 & & $\begin{array}{l}\text { thunin A } \\
\text { Bt wet powder }\end{array}$ & $\begin{array}{l}\text { Tryy } \\
\text { cylindrical steel containe }\end{array}$ \\
\hline Lactobarlllus delbrueckll & & Ladiczadd & Static flask \\
\hline $\begin{array}{l}\text { Lactobocillus sp. } \\
\text { Monassur pupuress }\end{array}$ & & Tanase & $\begin{array}{l}\text { Saticitfask } \\
\text { Staticflask }\end{array}$ \\
\hline Matierelli alpina & & polyunsaturated fatty acid & Column reactor \\
\hline 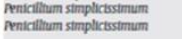 & & & $\begin{array}{l}\text { Satic flask } \\
\text { Fixed bed reactor }\end{array}$ \\
\hline Rhtsopus ayzae NRRL 11991 & & Phyase & Satic flask \\
\hline 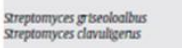 & & $\begin{array}{l}\text { Npha glactosidases } \\
\text { Cephanrycin C }\end{array}$ & $\begin{array}{l}\text { Satuic flask } \\
\text { Static flask }\end{array}$ \\
\hline $\begin{array}{l}\text { Mhemnoascaus auranticus } \\
\text { michoderma revert }\end{array}$ & & $\begin{array}{l}\text { Cellulase } \\
\text { celluase }\end{array}$ & $\begin{array}{l}\text { Perforated drum bioreac } \\
\text { Static flask }\end{array}$ \\
\hline $\begin{array}{l}\text { Michodema harzanum TUBF } \\
927\end{array}$ & & Chitobiase & Static flask \\
\hline 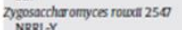 & sesume al cake & t-Glutaminase & static flask \\
\hline 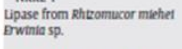 & Sucrose + free and calcuum & $\begin{array}{l}\text { Hexyl lusurte } \\
\text { palutinose }\end{array}$ & $\begin{array}{l}\text { Packed-bed bioreactor } \\
\text { Packed bed reactor }\end{array}$ \\
\hline Micobial biofilm developed & 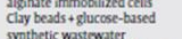 & Organic acids and hydrogen & Horizontal packed-bed \\
\hline $\begin{array}{l}\text { upase producing Ehropous } \\
\text { ange }\end{array}$ & cuboidal polyurethune farm & Da-diesel fuel & Packed-bed reactor \\
\hline Hydrogen produang sludger & 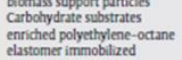 & Hydrogen and ethanol & $\begin{array}{l}\text { Fluidized-bed and pucker } \\
\text { reactor }\end{array}$ \\
\hline Clossidtum brobugrikum $M$ I & 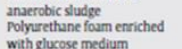 & Biological hydrogen & Fuxed-bed bicresctor \\
\hline
\end{tabular}

development of wonder drug, penicillin took place in submerged fermenta-tion (SmF), which was having enormous importance at that time. Research related to SSF always continued, though in isolated pock-ets. During 1950-1960, steroid transformation was reported using fungal culture and reports on mycotoxin production employing SSF appeared during 1960-1970, which enabled SSF to attain another milestone and it continued with the reports on production of pro-tein enriched cattle feed by SSF utilizing agro-industrial residues, thus offering a unique process development for value addition of these low cost residues which are also considered as pollutant to some extent.

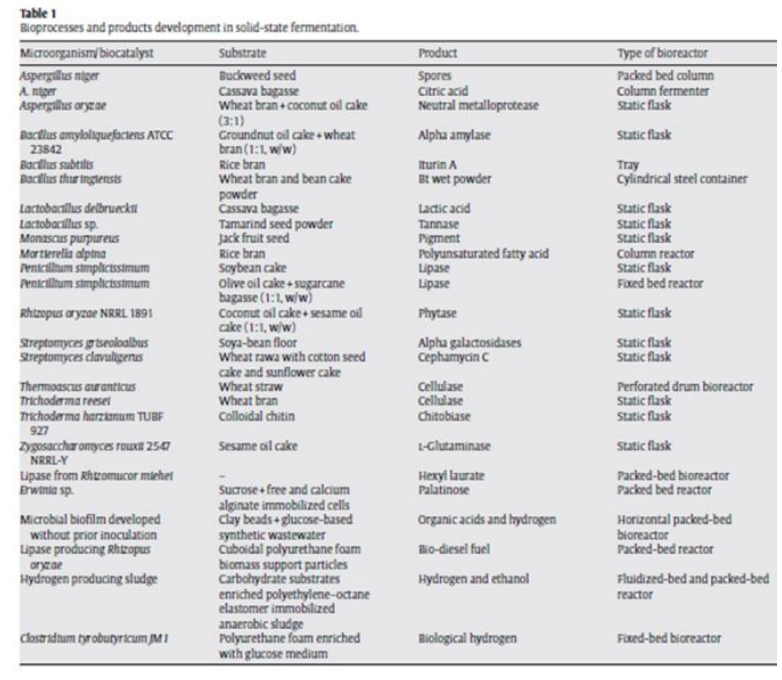

There has been a continuous extension of SSF arena, for the development of bioprocesses, such as bioremediation and biodegradation of hazardous compounds, biological detoxifi-cation of agroindustrial residues, biotransformation of crops and crop-residues for nutritional enrichment, biopulping, and produc-tion of value-added products, such as biologically active secondary metabolites, including antibiotics, alkaloids, plant growth factors, enzymes, organic acids, biopesticides, including mycopesticides and bioherbicides, biosurfactants, biofuel, aroma compounds, etc.

Thus, though historically known since centuries, SSF gained a fresh attention from researchers and industries all over the world since recent few years, mainly due to few advantages it offers over liquid (submerged) fermentation, particularly in areas of solid waste management, biomass energy conservation and its application to produce high value-low volume products such as biologically active secondary metabolites, etc., apart from the pro-duction of food, feed, fuel and traditional bulk chemicals (Singhania, et al., 2009).

Enzymes of commercial or industrial importance are obtained from three main sources namely plants, animals and microorganisms. In the past, plants and animals served as main source of enzymes but today microbial sources of enzyme are becoming more popular for obvious reasons. In order to obtain even a small quantity of plant enzymes, a large amount of plant materials has to be used and this renders large scale production of plant enzymes uneconomical, especially if the plant has some economic values or uses. Also difficulties are encountered in the extraction of the enzyme from plants (Abubakar and Oloyede, 2013).

Cellulase refers to a class of enzymes produced chiefly by fungi, bacteria and protozoan that catalyzed the cellulolysis (or hydrolysis of cellulose). Although there are also cellulose producing plants and animals, a large number of microorganism are capable of degrading cellulose, only a few of these 
microorganisms produce significant quantities of cell free enzyme capable of degrading cellulose in vitro. Fungi carry out extracellular digestion and secrete digestive enzyme into their substrates and absorb only digested food into their hyphae as such, they produce cell free enzyme. Fungi are the main cellulase producing microorganism in which Aspergillus sp. are known to hydrolyse both soluble and insoluble cellulose (Abubakar and Oloyede, 2013). For use as enzyme producers, cellulolytic fungi have the great advantage of both utilizing secretory pathways and the production of high protein yields. Additionally, other fungi, such as Penicillium, Acremonium and Chrysosporium are viewed as potential and promising alternatives to Trichoderma .For the efficient hydrolysis of cellulose, basically three typesof synergistically acting enzymes are necessary. Cellobiohydrolases, also named as exoglucanases (E.C. 3.2.1.176) (E.C. 3.2.1.91), attack the crystalline ends of cellulose producing cellobiose. Endoglucanases (EGs) (E.C. 3.2.1.4), split glycosidic bonds withinthe amorphous part of the substrate . Finally, the released cel-lobiose is cleaved by $\beta$ glycosidases (BGls) (E.C. 3.2.1.21) into glucose monomers (Bahera \& Ray, 2016)

Cellulase is used for commercial food processing in coffee. It performs hydrolysis of cellulose during drying of coffee beans. Furthermore, cellulase is widely used in textile industry and in laundry detergents. Cellulase has also been used in the pulp and paper industry for various purposes. They are even used in pharmaceutical applications. Cellulase is used in the fermentation of biomass into biofuels, although this process is relatively experimental. Cellulase is used as a treatment for phytobezoars, a form of cellulose bezoar found in the human stomach. Since the production of cellulase enzyme is a major factor in hydrolysis of cellulosic material, it is important to make the process economically viable. (Abubakar and Oloyede, 2013).

Lignocelluloses are the most generous renewable carbon resource in the world with production rate of 200 billion tons biomass per year (Anwar, et al, 2014). Lignocelluloses are mainly composed of cellulose (35-50\%), hemicelluloses (25$30 \%)$ and lignin (25-30\%). However, cellulose, the most important cell wall polysaccharide inplants is restored constantly in nature by photosynthesis (Yoon et al., 2014).

Therefore, this paper reviews cellulase production using SSF from waste. The waste consists of agriculture waste and food processing waste with various microorganism. Produced various grades of enzyme activity depends on the type of waste.

\section{Some Example of Cellulase Enzyme Production Using Solid State Fermentation From Waste \\ Palm Kernel Cake}

Palm kernel cake (PKC), is an agro-industrial residue created in the palm oil industry, and large quantities of PKC are produced in Malaysia. Sustainable development of the palm oil industry in Malaysia demands an economical technology for the environmentally friendly utilization of PKC in industrial utility systems. This research was carried out to evaluate the use of PKC in the production of cellulase by the cultivation of Aspergillus niger FTCC 5003 in a laboratory packed-bed bioreactor for seven days.

A central composite design was used to perform eighteen trials of solid substrate fermentation under selected conditions of incubation temperature, initial moisture content of substrate, and airflow rate. Experimental results showed that a cellulase yield of 244.53 U/g of dry PKC was obtained when $100 \mathrm{~g}$ of PKC was hydrolyzed at an incubation temperature of $32.5^{\circ} \mathrm{C}$, an initial moisture level of $60 \%$, and an aeration rate of $1.5 \mathrm{~L} / \mathrm{min} / \mathrm{g}$ PKC. An empirical second-order polynomial model was adjusted to the experimental data to evaluate the effects of the studied operating variables on cellulase production. The statistical model revealed that the quadratic term for initial moisture content had a significant effect on the production of cellulase $(\mathrm{P}<0.01)$. The regression model also indicated that the quadratic terms for incubation temperature and interaction effects between initial moisture content and aeration rate significantly influenced cellulase production $(\mathrm{P}<0.05)$. The empirical model determined that the optimum conditions for cellulase production were an incubation temperature of $31.0^{\circ} \mathrm{C}$, an initial moisture content of $59.0 \%$ and an airflow rate of $1.55 \mathrm{~L} / \mathrm{min} / \mathrm{g}$ PKC. (Abdeshahian et al., 2011).

\section{Coir Waste}

Aspergillus niger was used for cellulase production in solid state fermentation (SSF). The CMCase and FPase activities recorded in SSF were 8.89 and $3.56 \mathrm{U}$ per $\mathrm{g}$ of dry mycelial bran (DBM), respectively. Where as in Smf the CMase \& FPase activities were found to be 3.29 and $2.3 \mathrm{U}$ per $\mathrm{ml}$ culture broth, respectively. The productivity of extracellular cellulase in SSF was 14.6 fold higher than in SmF. The physical and nutritional parameters of fermentation like $\mathrm{pH}$, temperature, substrate, carbon and nitrogen sources were optimized. The optimal conditions for maximum biosynthesis of cellulase by A. niger were shown to be at $\mathrm{pH} 6$, temperature $30^{\circ} \mathrm{C}$. The additives like lactose, peptone and coir waste as substrate increased the productivity both in $\mathrm{SmF}$ and SSF. The moisture ratio of 1:2 (w/v) was observed for optimum production of cellulase in SSF (Mrudula and Murugammal, 2011).

\section{Rice Straw}

To investigate the production of cellulases and hemicellulases from Aspergillus niger KK2, solid state fermentation (SSF) was performed by using different ratios of rice straw and wheat bran. When $A$. niger KK2 was grown on rice straw alone as a solid support in SSF, the maximum FPase activity was $19.5 \mathrm{IU}$ g1 
in 4 days. Also, CMCase (129 IU g1), b-glucosidase (100 IU g1), xylanase (5070 IU g1) and b-xylosidase (193 IU g1) activities were concurrently obtained after 5-6 days of fermentation. The higher enzyme activities produced by A. niger KK 2 is a significant advantage from the viewpoint of practical saccharification reaction (Kang, et al., 2004).

\section{Black Beans}

Enzyme production from agrowastes through the microbial action seems to be very striking and sustainable due to the renewable and ubiquitous nature of biomass and its non-compotitiveness with food crops and these known to be an excellent carbon source for mocrobial enzyme production. The process parameters were optimized from for cellulase production by Aspergillus niger on Black beans or Vigno mungo in solid state fermentation solid state fermentation . Subtrate amanded with $0,2 \%$ ammonium sulphate as a nitrogen source at $30 \pm 2{ }^{\circ} \mathrm{C}$, $\mathrm{pH} 4,5$ and $70 \%$ of initial moisture after incubation of 96 hours produced maximum cellulase. Alkaline pretreatment with $1 \mathrm{~N}$ of $\mathrm{NaOH}$ accelerated cellulase activity by 1,51 folds as compared to untreated substrate (Ilyas et al., 2011).

\section{Banana Peel}

The feasibility of using banana peel for the production of cellulase by Trichoderma viride GIM 3.0010 in solid-state fermentation. The effect of incubation time, incubation temperature, initial moisture content of the medium, inoculum size and supplementation of carbon sources and nitrogen sources on cellulase production was investigated. When banana peel was moistened to the moisture content of $65 \%$ with the inoculum size of $1.5 \times 109$ spores / flask and incubated at $30^{\circ} \mathrm{C}$ for 144 $\mathrm{h}$, the maximum activities of filter paper activity (FPA), carboxy methyl cellulase sodium activity (CMCase) and $\beta$-glucosidase (BG) reached 5.56, 10.31 and $3.01 \mathrm{U} / \mathrm{gds}$, respectively. These results indicated that banana peel provided necessary nutrients for cell growth and cellulase synthesis. It can be used as a potential substrate for cellulase production by $T$. viride GIM 3.0010 under solid-state fermentation (Sun et al., 2011).

\section{Soybean Hulls}

The three components of the enzyme complex (endoglucanase, exoglucanase and $\beta$-glucosidase) can effectively depolymerize the cellulose chains in lignocellulosic substrate. Solid-state fermentation (SSF) by fungi is a preferable production route for cellulase because of its low cost, among other advantages. Cellulase production by Aspergillus niger NRRL3 grown on SSF. SSF was carried out on soybean hulls and waste paper as supports. Maximum endoglucanase activity was found at $96 \mathrm{~h}$ using soybean hulls as support (5914.29 U L 1), being four times higher than that obtained using waste paper at the same fermentation time. The exoglucanase activity in soybean hulls was maximal at $96 \mathrm{~h}(4551.19 \mathrm{U} \mathrm{L}$
1), being 9.6 times higher than that obtained in waste paper at the same time. The maximum $\beta$-glucosidase activity in soybean hulls (984.01 U L 1) was reached at $96 \mathrm{~h}$, being 1.7 times greater than that obtained in waste paper (Julia et al., 2016).

\section{Corn Brand}

The present study deals with the optimization of substrate and fermentation conditions for the production of both pectinase and cellulase by Aspergillus niger NCIM 548 under same fermentation conditions in submerged fermentation $(\mathrm{SmF})$ and solid state fementation (SSF) using a central composite face centered design of response surface methodology (RSM). As per statistical design, the optimum conditions for maximum production of pectinase (1.64 $\mathrm{U} / \mathrm{mL}$ in $\mathrm{SmF}$ and $179.83 \mathrm{U} / \mathrm{g}$ in $\mathrm{SSF}$ ) and cellulase $(0.36 \mathrm{U} / \mathrm{mL}$ in $\mathrm{SmF}$ and $10.81 \mathrm{U} / \mathrm{g}$ in $\mathrm{SSF})$ were, time $126 \mathrm{~h}, \mathrm{pH} 4.6$, and carbon source concentration $65 \mathrm{~g} / \mathrm{L}$ in $\mathrm{SmF}$ and were time $156 \mathrm{~h}, \mathrm{pH}$ 4.80 , and moisture content $65 \%$ in SSF. The response surface modeling was applied effectively to optimize the production of both pectinase and cellulase by $A$. niger under same fermentation conditions to make the process cost-effective in both submerged and solid state fermentation using agro industrial wastes as substrate (Kumar et al., 2011).

\section{Wheat Bran}

Aspergillus niger NRRL 3112 can produce considerable amounts of $\beta$-1,4-glucosidase (BGL) when grown on wheat bran and glycerol as cosubstrates. BGL production was first investigated in a stirred-tankbioreactor (STR) at $450 \mathrm{rpm}$ and $2 \mathrm{vvm}$. About 5.4 U/mL BGL was obtained using spore suspension asinoculum, where as a higher production of $9.3 \mathrm{U} / \mathrm{mL}$ was obtained using precultured cell pellets. The production of BGL in batch, fed batch and repeated batch modes in a rotating fibrous bed bioreactor (RFBB) was then studied and compared to the STR. The highest BGL productivity of 1.78 $\mathrm{U} / \mathrm{mL} /$ day was obtained in the RFBB operated at a repeated batch mode, which was slightly higher than that $(1.65 \mathrm{U} / \mathrm{mL} /$ day $)$ obtained in the STR with preformed cell pellets and about 1.75 fold of that (1.02 $\mathrm{U} / \mathrm{mL} /$ day) for the free-cell fermentation in STR inoculated with spores. This work demonstrated that the RFBB could provide anefficient process for $\beta$ glucosidase production from low-cost wheat bran and glycerol. (Abdella et al., 2016).

Fungal cellulases are well-studied enzymes and are used in various industrial processes. Much of the knowledge of enzymatic depolymerization of cellulosic material has come from Trichoderma cellulase system. Species of Trichoderma can produce substantial amounts of endoglucanase and exoglucanase but very low levels of b-glucosidase. This deficiency necessitates screening of fungi for cellulytic potential. A number of indigenously isolated fungi were screened for cellulytic potential. In the present study, the kinetics of cellulase production 
from an indigenous strain of Aspergillus niger MS82 is reported. Product formation parameters of endoglucanase and b-glucosidase $(\mathrm{Qp}+\mathrm{Yp} / \mathrm{s})$ indicate that $A$. niger MS82 is capable of producing moderate to high levels of both endoglucanase and bglucosidase when grown on different carbon containing natural substrates, for example, grass, corncob, bagasse along side purified celluloses. Furthermore, it was observed that the production of endoglucanase reaches its maximum during exponential phase of growth, while b-glucosidase during the Stationary phase. Enzyme production by solid-state fermentation was also investigated and found to be promising. Highest production of cellulase was noted at $\mathrm{pH} 4.0$ at $35,8{ }^{0} \mathrm{C}$ under submerged conditions. Growth and enzyme production was affected by variations in temperature and $\mathrm{pH}$. ( $\mathrm{Vu}$ et al., 2011).

\section{Grass, Corncob and Bagasse}

Fungal cellulases are well-studied enzymes and are used in various industrial processes. Much of the knowledge of enzymatic depolymerization of cellulosic material has come from Trichoderma cellulase system. Species of Trichoderma can produce substantial amounts of endoglucanase and exoglucanase but very low levels of b-glucosidase. This deficiency necessitates screening of fungi for cellulytic potential. A number of indigenously isolated fungi were screened for cellulytic potential. In the present study, the kinetics of cellulase production from an indigenous strain of Aspergillus niger MS82 is reported.

Product formation parameters of endoglucanase and b-glucosidase $(\mathrm{Qp}+\mathrm{Yp} / \mathrm{s})$ indicate that $A$. niger MS82 is capable of producing moderate to high levels of both endoglucanase and bglucosidase when grown on different carbon containing natural substrates, for example, grass, corncob, bagasse along side purified celluloses. Furthermore, it was observed that the production of endoglucanase reaches its maximum during exponential phase of growth, while b-glucosidase during the Stationary phase. Enzyme production by solid-state fermentation was also investigated and found to be promising. Highest production of cellulase was noted at $\mathrm{pH} 4.0$ at $35,8{ }^{0} \mathrm{C}$ under submerged conditions. Growth and enzyme production was affected by variations in temperature and $\mathrm{pH}$. (Sohail et al., 2009).

\section{Banan Stalk}

Bacillus subtilis was cultured in solid-state fermentation (SSF) of Banana stalk to produce exoglucanase. The fermented biomass was harvested after $72 \mathrm{~h}$ of SSF at $\mathrm{pH} 7$ and temperature $35^{\circ} \mathrm{C}$. It was filtered and centrifuged at $10,000 \mathrm{rpm}$ at $-10^{\circ} \mathrm{C}$ and supernatant was collected as crude enzyme extract. Maximum activity of exoglucanase $(3.48 \mathrm{IU} / \mathrm{mL} / \mathrm{min})$ was obtained from the medium fermented with $70 \%$ moisture content, $5 \mathrm{~mL}$ inoculum, $0.1 \%$ peptone, $0.4 \%$ yeast extract and $0.2 \%$ Tween 80 at $\mathrm{pH} 7$ and temperature $35^{\circ} \mathrm{C}$. SSF was found to be more productive than liquid state fermentation (LSF) in terms of exoglucanase yields. The partial purification of exoglucanase was carried out through $\left(\mathrm{NH}_{4}\right)_{2} \mathrm{SO}_{4}$ precipitation and maximum purification was achieved with $20 \%\left(\mathrm{NH}_{4}\right)_{2} \mathrm{SO}_{4}$ saturation. (Shafique et al., 2014).

\section{Pineapple Waste \\ Cellulase production from cellulosic pineapple waste using Trichoderma longibrachiatum,} Aspergillus niger and Saccharomyces cerevisiae was assessed. The wastes were dried, pre-treated with alkali and steam, re-dried and then blended. The powdered wastes were then used as substrates in separate shake-flasks which contained mineral salts medium (MSM) and inoculi of Trichoderma longibrachiatum, Aspergillus niger and Saccharomyces cerevisiae. Fermentations were carried out in flasks containing the MSM, the waste substrate and the inoculum at $\mathrm{pH} 5.0,1 \%$ substrate concentration, $10 \%$ inoculum size and cultured on a rotary shaker at $29 \pm 1^{\circ} \mathrm{C}$ initially for 5 days to verify cellulase production by the organisms from the waste substrates, then for 7 days or 9 days while varying different fermentation parameters. Cellulase activity and amount of glucose produced by the three test organisms from the waste substrates were determined and compared.

The amount of glucose produced was optimized by varying the fermentation parameters: Time, pH, Substrate concentration, Inoculum size and Temperature. The results obtained from the fermentations showed that Trichoderma longibrachiatum produced the highest amount of glucose among the cultures tested $(0.92 \mathrm{mg} / 0.5 \mathrm{ml})$. This was produced from pineapple pulp at $\mathrm{pH} 4.5$ and temperature of $45^{\circ} \mathrm{C}$ on Day7 of fermentation. The highest amount of glucose produced by Aspergillus niger was also from pineapple pulp $(0.63 \mathrm{mg} / 0.5 \mathrm{ml})$ at $\mathrm{pH} 3.5$ and temperature of $40^{\circ} \mathrm{C}$ on Day 5 of fermentation. The highest amount of glucose produced by Saccharomyces cerevisiae was from pineapple pulp $(0.54 \mathrm{mg} / 0.5 \mathrm{ml})$ at $\mathrm{pH} 4.5$ and temperature of $45^{\circ} \mathrm{C}$ on Day5 of fermentation. (Omojasola et al., 2008).

\section{Conclusion}

Critical analysis of the literature shows that production of relevant compounds for the cellulase production by SSF offers several advantages. It has been well established that enzyme titres produced in SSF systems are much higher than the achieved in SmF ones.

\section{References}

Abdeshahian, P., Samat, N., Hamid, A.A., Yusof, W. (2011). Solid Substrate Fermentation for Cellulase Production Using Palm Kernel Cake as a Renewable Lignocellulosic Source in 
Packed-bed Bioreactor. Biotechnology and Bioprocess Engineering 16: 238-244 (2011).

Abdella, A., Mazeed, T.E., El-Baz, A.F., Zang, S.T. (2016). Production of -glucosidase from wheat bran and glycerol byAspergillus niger in stirred tank and rotating fibrous bed bioreactors. Process Biochemistry.

Abubakar, F.A and Oloyede, O.B. (2013). Production and activity of cellulase from Aspergillus niger using rice bran and orange peel as substrates. International Journal of scientific research and management IJSRM Volume 1 Issue 5 Pages 285-291 (2013) Website: www.ijsrm.in ISSN (e): 2321-3418.

Anwar, Z., Gulfraz, M., Irshad, M. (2014). Agroindustrial lignocellulosic biomass akey to unlock the future bio-energy: a brief review, $J$. Rad. Res. Appl. Sci. 7(2014) 163-173.

Ashok Pandey .(2003). Solid-state fermentation. Biotechnology Division, Regional Research Laboratory, Council of Scientific and Industrial Research, Trivandrum-695 019, India. Biochemical Engineering Journal 13 (2013) vol 81-84.

Bahera, S.S.,Ray, R.C. (2016). Solid state fermentation for production of microbial cellulases : Recent advances and improvement strategies. International Journal of Biological Macromolecules 86 (2016) 656-669.

Couto, S.R., Sanroman, M.A. (2006). Application of solid-state fermentation to food industry-A review. Journal of Food Engineering 76 (2006) vol 291-302.

Ilyas, U., Majeed, A., Hussain, K., Nawaz, K., Ahmed, S., Nadeem, M. (2011). Solid State Fermentation of Vigno mungo for cellulase production by Aspergillus niger. Wolrd Applied Science Journal 12(8): 1172-1178, 2011

Julia, B.M., Belen, A.M., Georgina, B., Beatriz, F. (2016). Potential use of soybean hulls and waste paper as supports in SSF for cellulase production by Aspergillus niger. Biocatalysis and Agricultural Biotechnology 6 (2016) 1-8.

Kang, S.W., Park, Y.S., Lee, J.S., Hong, S.I., Kim, S.W. (2004). Production of cellulases and hemicellulases by Aspergillus niger KK2 from lignocellulosic biomass. Bioresource Technology 91 (2004) 153-156.

Kumar, S., Sharma, H.K., Sarkar, B.C. (2011). Effect of Substrate and Fermentation Conditions on Pectinase and Cellulase Production by Aspergillus niger NCIM 548 in Submerged (SmF) and Solid State Fermentation (SSF). Food Sci. Biotechnol. 20(5): 1289-1298

Mrudula, S., Murugammal, R. (2011). Production of cellulase by Aspergillus niger under submerged and solid state fermentation using coir waste as a substrate. Brazilian Journal of Microbiology (2011) 42: 1119-1127.
Omojasola, P. Folakemi, Jilani, Priscilla, O., and Ibiyemi, S.A .(2008). Cellulase Production by some Fungi Cultured on Pineapple Waste. Nature and Science, 6(2), 2008 ISSN: 15450740 .

Shafique, S., Asgher, M., Sheikh, M.A., asad, M.J. (2004). Solid State Fermentation of Banana Stalk for Exoglucanase. International journal of agriculture \&biology 1560-8530/2004/063-488-491. http://www.ijab.org

Singhania, R.R., Patel, A.K., Soccol, C.R., Panday, A. (2009). Recent advances in solid-state fermentation. Biochemical Engineering Journal 44 (2009) vol 13-18.

Sohail, M., Siddiqi, R., Ahmad, A., Khan, A. (2009), Cellulase production from Aspergillus niger MS82: effect of temperature and $\mathrm{pH}$. New Biotechnology Volume 25, Number 6.

Sun, H.Y., Li, J., Zhao, P., Peng, M. (2011). Banana peel: A novel substrate for cellulase production under solid-state fermentation. African Journal of Biotechnology Vol. 10(77), pp. 1788717890.

Vu, V.H., Pham, T.A., Kim, K. (2011). Improvement of Fungal Cellulase Production by Mutation and Optimization of Solid State Fermentation. Mycobiology 39(1) : 20-25 (2011) (C) The Korean Society of Mycology.

Yoon, L.Y., Ang, T.N., Ngoh, G.C. (2014). Fungal solid-state fermentationand various methods of enhancement in cellulase production, BiomassBioenergy 67 (2014) 319-338. 